\title{
HIGH MOLECULAR DIVERSITY \\ IN CARABUS (HYGROCARABUS) VARIOLOSUS AND C. NODULOSUS
}

\author{
Dietrich Mossakowski ${ }^{1}$, SÁndor Bérces ${ }^{2}$, Radek Hejda ${ }^{3}$ \\ Stefan Müller-Kroehling ${ }^{4}$, Wolfgang Paill ${ }^{5}$, Florin Prunar $^{6}$ and Ivan Rapuzzi ${ }^{7}$ \\ ${ }^{1}$ Seeweg 10, D-23942 Gross Schwansee, Germany; \\ E-mail:dmossa@t-online.de; https://orcid.org/0000-0001-8409-6027 \\ ${ }^{2}$ University of Debrecen, Juhász-Nagy Pál Doctoral School, H-4032 Debrecen, Egyetem tér 1, \\ Hungary; E-mail: bercess@gmail.com; https://orcid.org/0000-0003-2920-8756 \\ ${ }^{3}$ Nature Conservation Agency of the Czech Republic, Kaplanova 1931/1, \\ CZ-148 00 Praha 11 - Chodov, Czech Republic; E-mail: radek.hejda@nature.cz \\ ${ }^{4}$ Bavarian State Institute of Forestry, Hans-Carl-von-Carlowitz-Platz 1, DE-85354 Freising, \\ Germany; E-mail: Stefan.Mueller-Kroehling@lwf.bayern.de \\ ${ }^{5}$ Studienzentrum Naturkunde, Weinzöttlstraße 16, A-8045 Graz, Austria \\ E-mail: wolfgang.paill@museum-joanneum.at; https://orcid.org/0000-0003-2542-5569 \\ ${ }^{6}$ Banat's University of Agricultural Sciences and Veterinary Medicine \\ 119 Calea Aradului, RO-300645 Timisoara, Romania \\ E-mail: foprunar@gmail.com; https://orcid.org/0000-0003-4318-1107 \\ ${ }^{7}$ Via Cialla, 47, I-33040 Prepotto (UD), Italy \\ E-mail: info@ronchidicialla.it; https://orcid.org/0000-0002-5644-6218
}

The Carabus subgenus Hygrocarabus contains two taxa: C. variolosus and C. nodulosus, the species or subspecies status of which is handled far from uniform in the literature. Both taxa show a similar morphology, the shape of the tip of the aedeagus provides a reliable morphological marker for identification. We analysed two mitochondrial gene parts (COI-5' and COI-3') and a nuclear one (ITS2). High diversity was found showing specific geographical patterns. Introgressive hybridisation was detected but interpreted not as an argument for subspecies status because high genetic distances indicated that it must have taken place in former times. In a laboratory hybridisation experiment, the male did not accept the female of the other taxon, supporting the conclusion that these are separate species. A series of refuges was expected for the period of ice ages. Although only the taxon C. variolosus is listed in Annex II and IV of the EU Habitats Directive, C. nodulosus also falls under this listing, as at the time of including the species into the Annexes in 2004, the two taxa were considered subspecies and hence the listing would include both, independent of later taxonomic revisions.

Keywords: diversity, COI, ITS2, species versus subspecies, introgression, refuges, Carabus (Hygrocarabus) variolosus, Carabus nodulosus.

\section{INTRODUCTION}

The genus Carabus (Coleoptera, Carabidae) has high variability within species, which often causes problems with the species assignment. The Hygrocarabus taxa were described as Carabus variolosus Fabricius, 1787 and C. vari- 
olosus nodulosus Creutzer, 1799. In contrast to other Carabus spp., they show minimal morphological differences and a few slightly different characters that lead Casale et al. (1982) to establish them as separate species. Additionally, natural and experimental hybrids (e. g. Puisseguir 1964, Allemande \& Malausa 1984, Deuve 2004) and introgression events are frequently found: Chrysocarabus solieri (Rasplus et al. 2000), Ohomopterus spp. (Sota et al. 2000, Sota \& Vogler 2001, Sota et al. 2001, Ujji et al. 2005, Nagata et al. 2007), Chrysocarabus splendens - C. rutilans (Düring et al. 2000, 2006), Chrysocarabus splendens - C. punctatoauratus (Streiff et al. 2005), Coptolabrus spp. (Zhang et al. 2005), Leptocarabus spp. (Zhang \& Sota 2007), Mesocarabus spp. (Andujar 2012, Andujar et al. 2012) and Limnocarabus clathratus (MоssaKowsкi 2016). However, COI sequences show extremely low variability within and between German, Austrian and Slovenian C. nodulosus populations and moderate differences in C. variolosus (Matern et al. 2010).

The starting point of this study was the hypothesis that molecular data would reveal the subspecies status of the two taxa and give some insight into the phylogeography of their populations.

The subgenus name Hygrocarabus indicates a high adaptation to the water where larvae, as well as adults, hunt for prey (STURANi 1963). The structure of the elytra is unique and may be seen as an adaptation to this lifestyle (Fig. 1). This extreme hygrophilic species is adapted to moderately cold temperatures and can be found at the upper stretches of small rivers and creeks, from lowlands (C. nodulosus: old record from Hamburg $50 \mathrm{~m}$, Arnsberg $250 \mathrm{~m}$ ) to $1000 \mathrm{~m}$ a.s.l. (C. variolosus, Turin et al. 2003); adults overwinter close to water. A first map (BReuning 1926) shows a more or less Central European distribution area. C. variolosus is restricted to the Carpathians, C. nodulosus occurs from the Balkans to northern Germany and the Massif Central in France.

Our aim in this study is to test three hypotheses.

H1: The taxa C. variolosus and C. nodulosus constitute one species. This can be tested by looking for hybrids in nature, by crossbreeding laboratory experiments and by an analysis of DNA sequences of mitochondrial and nuclear genes.

H2: High genetic variability. MATERn et al. (2010) found high variability of enzymes in C. nodulosus populations but very low one in their sequence data. We expected a higher sequence variability looking on the whole distribution area although the Hygrocarabus taxa were morphologically very unique.

H3: The analysis of genetic variability will reveal the existence of refuges during the Pleistocene: south of the Holdhaus line (Holdhaus 1954) and north or above of the Mediterranean vegetation zone of garrigue and macchia. 


\section{MATERIAL AND METHODS}

\section{Crossbreeding experiments}

Live specimens of $C$. variolosus adults ( 1 male, 2 females) were collected in the Zemplén Mountains (Nagyhuta, Rostalló-patak), and those of C. nodulosus (14 males, three females) in Eastern Bakony (Réde, Küllőfeji-ér), which is part of the Transdanubian Mountains, both in Hungary. The two locations are $280 \mathrm{~km}$ apart. The beetles were collected between 15 May and 3 June 2020 and stored separately. The male and females of the different taxa were put in the same box for about $30 \mathrm{~min}$ on June 5 and again on June 10 to test whether crossbreeding occurs. On the second date, males were put to females of the same taxon immediately after the crossbreeding test.

\section{DNA isolation}

We obtained specimens from almost all regions of the distribution area except the westernmost part (Jura Mts and Massif Central, France). Besides fresh or recent specimens collected in the monitoring programmes for the species, we analysed dry specimens from collectors and museums. The latter samples gave results also, but in many cases, only a shorter part of the sequence and only mitochondrial data. A leg or in some cases thorax muscles were sent to the Advanced Identification Methods (AIM) Laboratory, in Munich, Germany, for DNA extraction and sequencing. For further details, see MossAKоwsкi (2016).

\section{Molecular methods}

We analysed parts of the mitochondrial genes cytochrome oxidase subunit 1 (COI-5' and COI-3') and NADH dehydrogenase subunit 5 (ND5) as well as the nuclear internal transcribed spacer 2 (ITS2) and the wingless gene. The ND5 and wingless genes gave in-

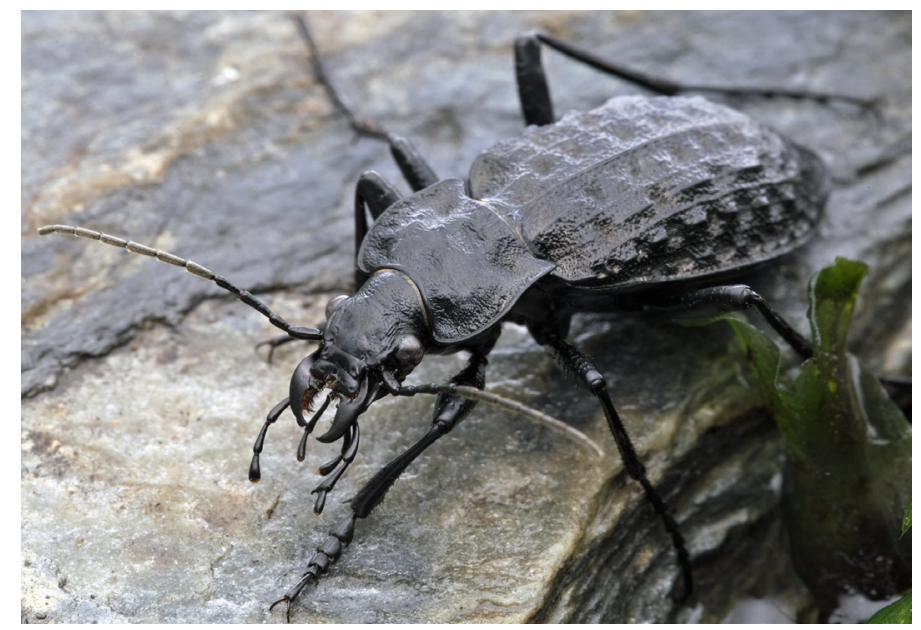

Fig. 1. Carabus variolosus male from Zemplén Mts, Hungary. (Photo: Sándor Bérces) 
Table 1. Patterns of sequence COI variability in Carabus variolosus and C. nodulosus. All variable positions included, except such only with singletons. HTG: Haplotype groups. Yellow: singletons or ambiguity; grey: missing data; dark green: exclusive for a group; light green: exclusive but with a few exceptions; dark blue: exclusive, pale blue: in different groups, orange-coloured: in contrast to green

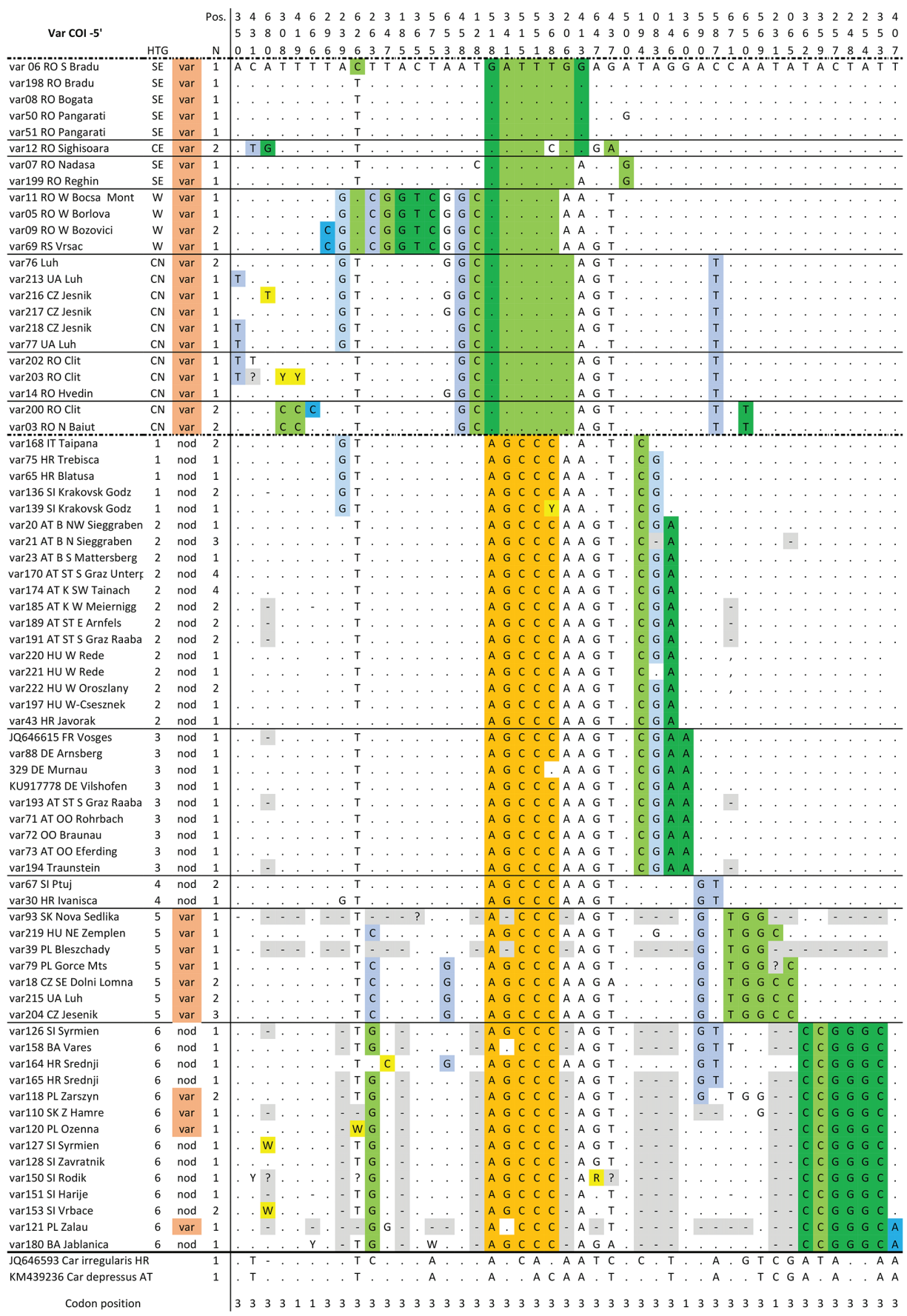


Table 2. Mean COI-5' Kimura-2-distances (\%) within and between groups of Carabus variolosus and C. nodulosus. HTG: Haplotype groups.

\begin{tabular}{|c|c|c|c|c|c|c|c|c|c|c|c|c|}
\hline \multicolumn{4}{|c|}{ Distances COI-5' } & \multirow{2}{*}{$\frac{1-3}{16}$} & \multirow{2}{*}{4} & \multirow{2}{*}{$\begin{array}{l}5 \\
7 \\
\end{array}$} & \multirow{2}{*}{$\begin{array}{c}6 \\
10 \\
\end{array}$} & \multirow{2}{*}{$\begin{array}{c}\mathrm{CE} \\
1\end{array}$} & \multirow{2}{*}{$\begin{array}{c}\text { SE } \\
7\end{array}$} & \multirow{2}{*}{$\frac{W}{4}$} & \multirow{2}{*}{$\begin{array}{c}\mathrm{CN} \\
10\end{array}$} & \multirow[t]{2}{*}{ OUT } \\
\hline HTG & $\mathrm{mt}$ & morph & $\mathrm{N}$ & & & & & & & & & \\
\hline $1,2,3$ & nod & nod & 16 & 0.60 & 1.19 & 1.89 & 3.06 & 2.26 & 2.23 & 3.34 & 2.75 & \\
\hline 4 & nod & nod & 3 & 1.19 & 0.66 & 1.93 & 3.14 & 2.28 & 2.33 & 3.30 & 2.45 & \\
\hline 5 & nod & var & 6 & 1.89 & 1.93 & 0.63 & 3.02 & 2.87 & 2.85 & 3.58 & 3.52 & \\
\hline 6 & both & both & 10 & 3.06 & 3.14 & 3.02 & 1.49 & 4.21 & 4.55 & 5.44 & 4.29 & \\
\hline $\mathrm{CE}$ & var & var & 1 & 2.26 & 2.28 & 2.87 & 4.21 & - & 1.14 & 2.85 & 2.31 & \\
\hline SE & var & var & 7 & 2.23 & 2.33 & 2.85 & 4.55 & 1.14 & 0.52 & 2.17 & 1.80 & \\
\hline W & var & var & 4 & 3.34 & 3.30 & 3.58 & 5.44 & 2.85 & 2.17 & 0.37 & 2.45 & \\
\hline $\mathrm{CN}$ & var & var & 10 & 2.75 & 2.45 & 3.52 & 4.59 & 2.31 & 1.80 & 2.45 & 0.71 & \\
\hline OUT & \multicolumn{2}{|c|}{ C. depressus } & 1 & 8.74 & 8.40 & 8.93 & 10.4 & 8.2 & 7.39 & 9.80 & 9.23 & 4.60 \\
\hline OUT & \multicolumn{2}{|c|}{ C. irregularis } & 1 & 10.80 & 10.95 & 11.02 & 12.1 & 10.7 & 9.96 & 12.15 & 11.95 & \\
\hline
\end{tabular}
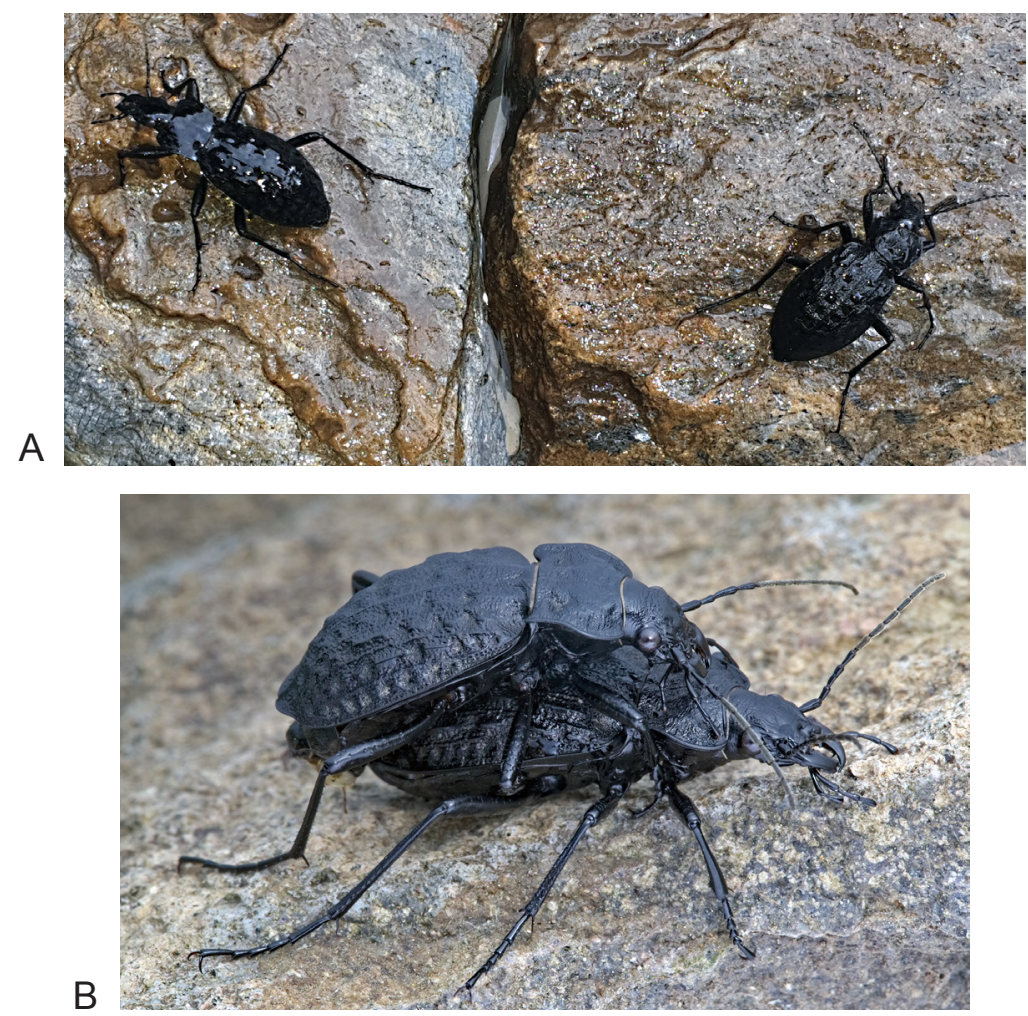

Fig. 2. Mating behaviour of Carabus variolosus and C. nodulosus in the laboratory. A: No interest to mate between $C$. variolosus male (left) and C. nodulosus female (right). B: Copulation took place immediately after putting together male and female C. variolosus. (Photos: Sándor Bérces) 
Table 3. Bases at all positions that show differences in Carabus variolosus (var) and C. nodulosus (nod) ITS2 sequence data. Colours indicate base distribution. N: Total number of specimens with identical sequences. Top lines: Position numbers.

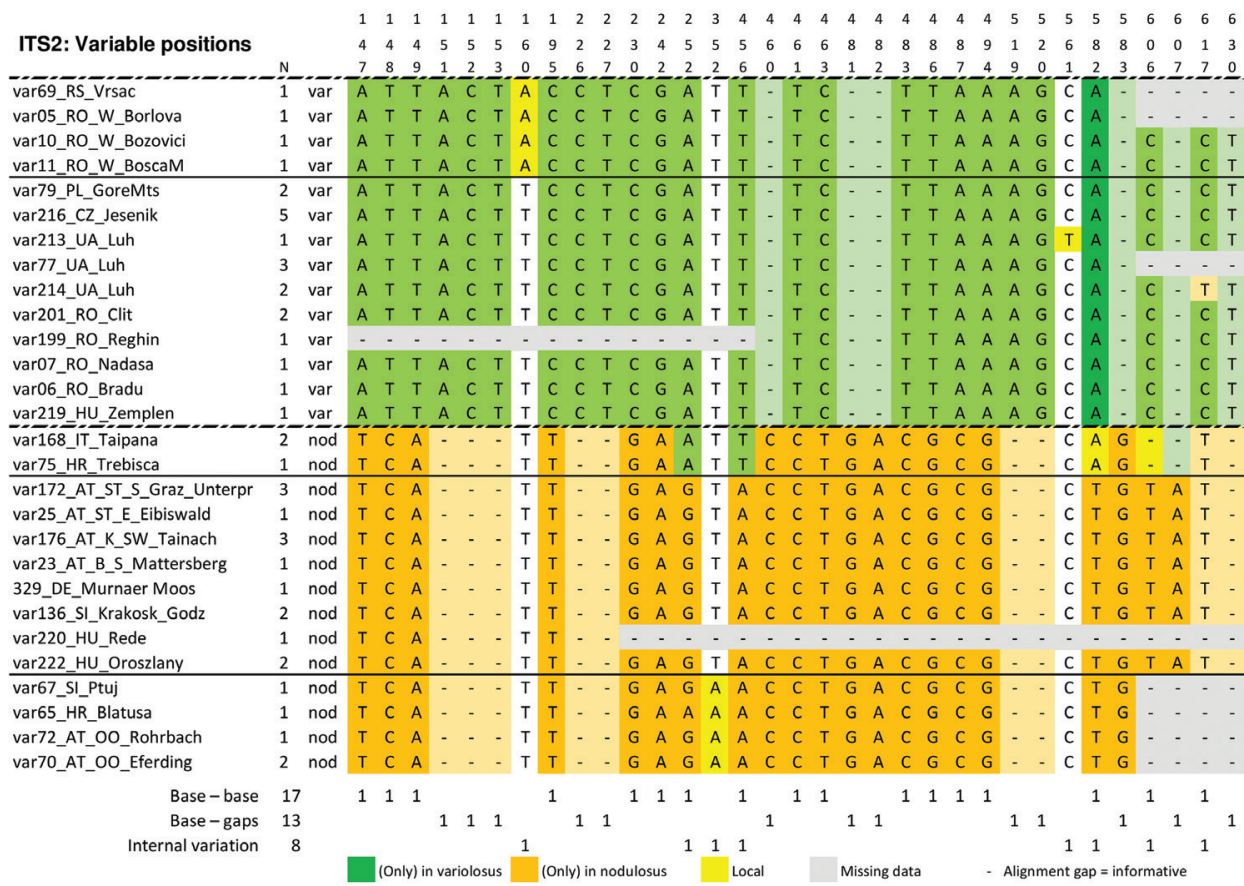

sufficient data and were omitted in the analyses. Editing and alignment of the sequences were done using CHROMAS (2008), BLAST (Altschul et al. 1990) and the Seqotron (FourMent \& Holmes 2016) programs. Phylogenetic and molecular evolutionary analyses were conducted using the MEGA version X (Kumar et al. 2018, Stecher et al. 2020), trees and distances were calculated with the clock function, the Kimura 2-parameter and the GTR + $\Gamma+$ I model. We analysed branch support using bootstrap analyses (FELSENSTEIN 1985). We looked for compensatory base changes in ITS2 with 4SALE (SEIBEL et al. 2006).

Phylogenetic trees are an abstract representation of results and sometimes not so easy correctly understood by people untrained to read them. Therefore, we display our sequence data in detail: All base positions with differences were shown and arranged in clusters (Table $1 \& 3$ ).

\section{RESULTS}

\section{Crossbreeding experiments}

Neither males nor females of either taxa tried to mate with the other one (Fig. 2A). The individuals collected were sexually mature because C. variolosus males and females started copulating immediately after being put together; the same happened with C. nodulosus (Fig. 2B). A C. nodulosus male even tried to copulate with another male, a phenomenon also observed in the field (Vértes Mts, Hungary, S.B. ). 

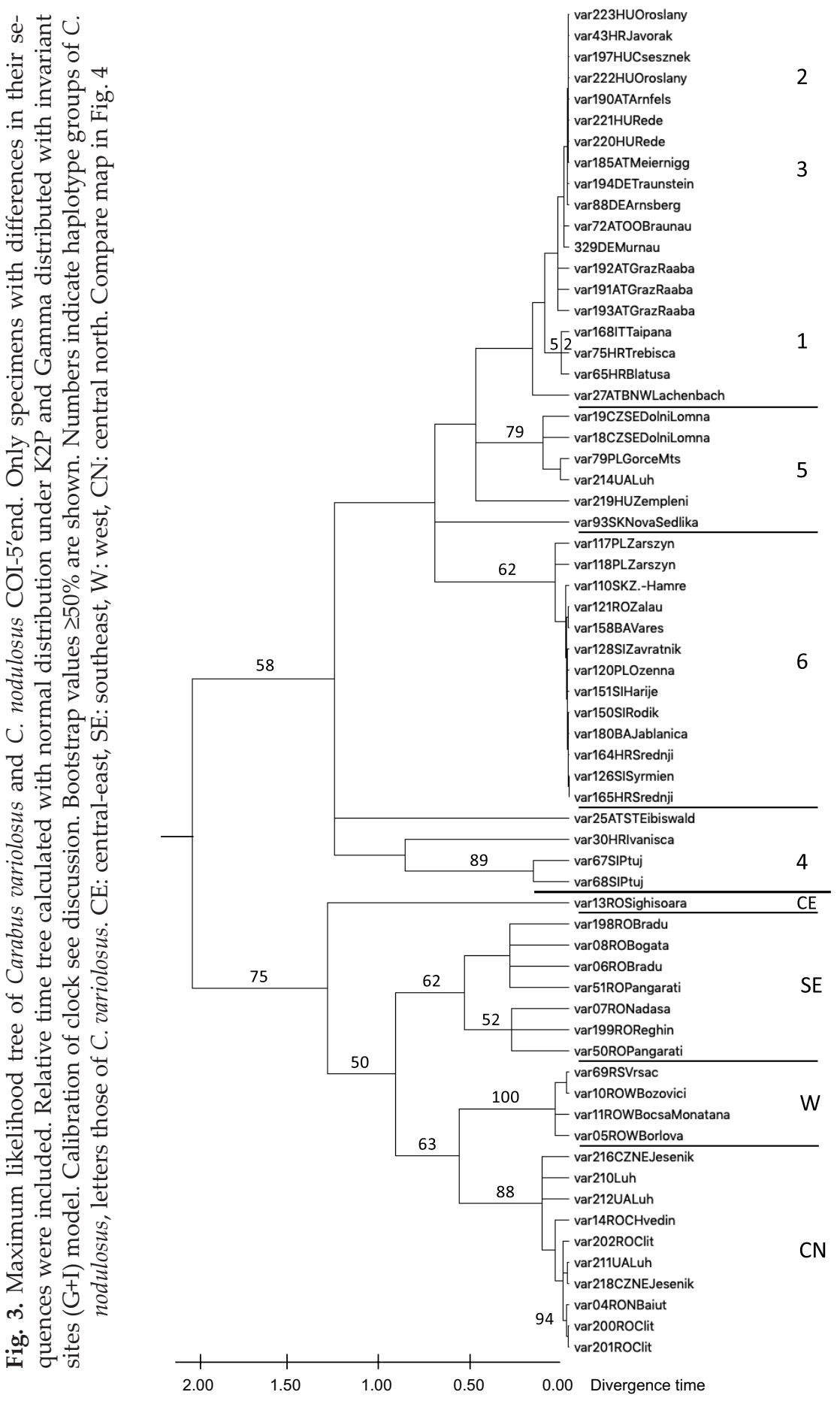


\section{Molecular sequence data}

Mitochondrial COI-5' end (barcode sequence) - Although the bootstrap values were low, C. variolosus and C. nodulosus were separated in the Maximum Likelihood tree. Ten haplotype groups (HTG) were established (Fig. 3 \& Table 1), seven in C. nodulosus and four in C. variolosus. The most remarkable result was the occurrence of $C$. nodulosus haplotypes (HTG 5 and 6) in populations of $C$. variolosus. This is an indication that $C$. nodulosus specimens migrated up to the region of the Carpathian Arc and that an introgression took place in former times (see discussion).

The data of the COI-3' end were fewer and displayed lower variability than those of COI-5'end but showed a pattern consistent with them. They were also more variable than those of MATERn et al. (2010) due to the larger geographical area under study (data not shown).

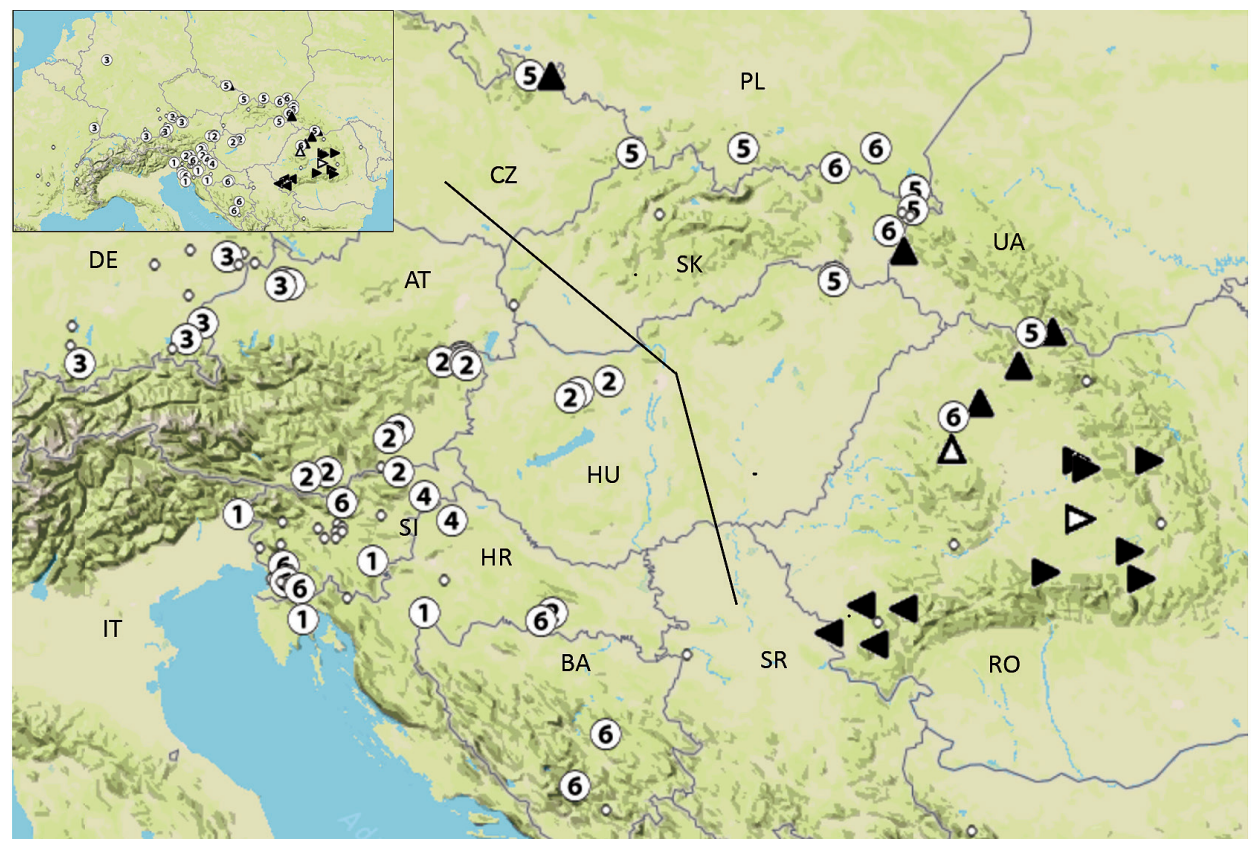

Fig. 4. Distribution of COI-5' haplotype groups of Carabus variolosus (triangles) and C. nodulosus (circles). C. variolosus occurs in the Carpathian Mountains (east of dividing line), C. nodulosus west of it. Circles in the $C$. variolosus area indicate $C$. variolosus specimens with a C. nodulosus haplotype indicating former introgression events. Line adapted from the map of BREUNING (1926). Different haplotype groups were marked by numbers or direction of the triangle. Open triangles indicate probable extra refuges. AT: Austria, BA: Bosnia and Herzegovina, CZ: Czech Republic; DE: Germany, HR: Croatia, HU: Hungary, IT: Italy, PL:

Poland, RO: Romania, RS: Serbia, SI: Slovenia, SK: Slovakia, UA: Ukraine 
Table 4. Numbers of ITS2 sequence differences in Hygrocarabus compared to other Carabus spp.

\begin{tabular}{lccccc}
\hline & \multirow{2}{*}{$\begin{array}{c}\text { No. } \\
\text { speci- } \\
\text { mens }\end{array}$} & \multicolumn{3}{c}{$\begin{array}{c}\text { Numbers of ITS2 sequence } \\
\text { differences }\end{array}$} \\
\cline { 3 - 6 } & base-base & base-gap & total \\
\hline Macrothorax morbillosus - Chrysocarabus spp. & $1-11$ & 16 & 30 & 46 \\
C. (Hygrocarabus) variolosus - C. nodulosus & $13-18$ & 17 & 13 & 30 \\
Chrysocarabus rutilans - C. hispanus & $2-1$ & 7 & 14 & 21 \\
C. problematicus - C. dufouri & $8-22$ & 6 & 11 & 17 \\
C. problematicus - C.lusitanicus & $20-66$ & 10 & 2 & 12 \\
C. problematicus - C. macrocephalus & $20-29$ & 11 & 3 & 14 \\
C. lusitanicus - C. macrocephalus & $66-29$ & 3 & 12 & 15 \\
\hline
\end{tabular}

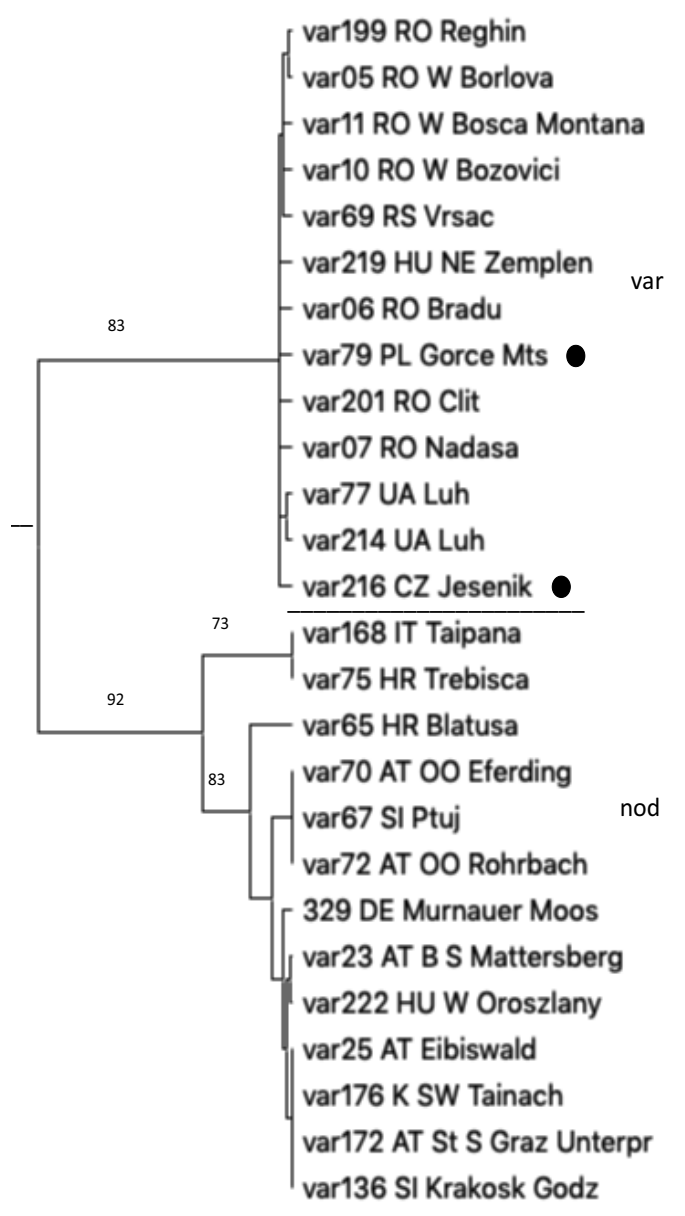

Nuclear gene: ITS2 - There was a clear separation between $C$. variolosus and $C$. nodulosus with sufficient bootstrap support (Fig. 5). Two dot-marked specimens of C. variolosus had a mitochondrial sequence of $C$. nodulosus. They showed a hybrid character but belonged to $C$. variolosus by distribution area, morphology and confirmed by a sequence of a nuclear gene. They did not represent recent hybridisation events (see discussion).

Many base differences showed the same pattern (Table 3). A clear differentiation occurred between the two taxa. The ITS2 substitutions were classified

Fig. 5. ITS2 tree of C. variolosus (var) and C. nodulosus (nod) specimens. Reduced data set without identical sequences of the same or different locations. The tree was rooted by C. irregularis. Black dots indicate variolosus specimens with a nodulosus mitochondrion. Compare data in Table 4 
Table 5. Calibration of COI-5' in Carabus variolosus and C. nodulosus, respectively. We took the split distance between south-eastern populations of $C$. variolosus (SE) and the probably oldest group (HTP 6) of C. nodulosus as basis: 4.55 was set as 1.00 (K2P distances; pairwise rate of $2.26 \% / \mathrm{my})$. Splits correspond to those in Fig. 3.

\begin{tabular}{lccc}
\hline Splits & & Parts & Mya \\
\hline variolosus & nodulosus & 1.00 & 2.01 \\
CE - Rest & $4-1-6$ & 0.45 & 0.91 \\
SE - CN, W & $6-1-5$ & 0.30 & 0.60 \\
CN - W & $5-1-3$ & 0.25 & 0.50 \\
Within SE & within 1-3, 5 & 0.20 & 0.39 \\
\hline
\end{tabular}

into three categories (Table 3). Bases - base and base - gap substitutions added up to 30 informative differences between C. variolosus and C. nodulosus, a high value when compared to species differences of other Carabus subgenera (Table 4).

\section{DISCUSSION}

Are the $\mathrm{C}$. variolosus and $\mathrm{C}$. nodulosus one species?

The taxonomic status of Carabus variolous and C. nodulosus is not consistent. Several authors classify them as two species (CASAle et al. 1982, Deuve 2004, 2019, Szél et al. 2008, Lorenz 2019), most, however, consider them subspecies (Breuning 1926, GuÉorguiev \& Guéorguiev 1995, Vreczec 2007, MaTern 2010, Curcic \& Stankovic 2011, Březina et al. 2017, Tallósi \& Mesaroš 2020; for a review see Müller-Kroenling 2006). Casale et al. (1982) classified them as semi-species from an evolutionary viewpoint.

Natural and experimental hybrids - The genus Carabus is well known for natural hybridisation (c.f. Deuve 2004), and numerous experimental hybrids are described (Puissegur 1964, Allemand \& Malausa 1984). The question, whether this occurs between $C$. nodulosus and C. variolosus, however, is hampered by the difficulties of keeping them in captivity. Mario StURANi (1962) could rear larvae but no adults. Other Italian colleagues were not successful, either, in rearing $C$. nodulosus (A. Casale, personal communication). This difficulty may be due to the very specialised biology of the species. These beetles need shallow waters and swampy ground (Sturani 1963, Koth 1974, Matern et al. 2008). Only Lassalle and Renaut (2008) succeeded by using a complicate technique of circulating water.

Species concepts are numerous (Mayden 1997). We followed the one defined by Dobzhansкy (1970: 374): 'A biological species is an inclusive Mendelian population; it is integrated by the bonds of sexual reproduction and parentage'. 
No hybrids between C. nodulosus and C. variolosus are known either from nature or from laboratory experiments. Although our experiments were of short duration, we could not observe mating behaviour between $C$. nodulosus and $C$. variolosus; however, the same specimens copulated immediately when put together with conspecifics. This is a strong argument for species status of the two taxa although the mechanisms behind this behaviour remain unclear.

\section{Indirect method: DNA sequences of mitochondrial and nuclear genes}

Sequence patterns - Mitochondrial and nuclear patterns differed clearly. The nuclear ITS2 sequences gave significant differences between the two taxa (Fig. 5 and Tables $3 \& 4$ ) as expected for different species. Both mitochondrial sequences exhibited divergent patterns of variability. The barcode region of COI had a few positions with deviating bases between the taxa, but this pattern was not strict, a base widespread in C. variolosus occurred also in C. nodulosus in one or a few cases; and vice versa. Both parts of COI showed a high variability indicating a high diversity within the taxa. The mitochondrial data (Table 1) support a subspecies status, which is in line with the conclusions drawn by MATERn et al. (2010).

The data of the ITS2 sequences were compared with data of other Carabus species to get a basis for the evaluation. The numbers of ITS2 substitutions between $C$. variolosus and $C$. nodulosus were counted and compared to data on Chrysocarabus, Macrothorax (DüRING et al. 2006) and Mesocarabus (AndujAR 2012) (Table 4).

Very few substitutions were found within and between Chrysocarabus spp., a subgenus well known for its crossbreeding ability (Allemand \& Malausa 1984). Numerous base substitution existed between the subgenera Chrysocarabus and Macrothorax. At the species - species level, we also found a high degree of differentiation between $C$. variolosus and $C$. nodulosus, lower than between the subgenera Chrysocarabus vs. Macrothorx (Table 4) but higher than those between the Mesocarabus spp.

These data support species status of $C$. (Hygrocarabus) variolosus and $C$. nodulosus.

\section{Distances and temporal aspects}

A high genetic distance between two taxa may indicate a species status, but there is no general limit. RAUPACH et al. (2010) found a minimum Kimura 2-parameter interspecific distance of 3.14\% among a wide range of carabid species. Pentisaari (2014) found a mean of 2.2\% (min. 0, max. 3.76\%) withinand $7.27 \%(0-13.45 \%)$ between-species distance in carabids. The carabid ge- 
nus Amara has three species pairs with a COI Kimura 2-parameter distance of $2.2 \%$ lower as normal for species (RAUPACH et al. 2018).

The COI-5' distances found in our study depended on the population group compared. Within C. nodulosus mean Kimura 2-parameter distances were $<2 \%$ except for haplotype group 6 that underlaid introgression into $C$. variolosus. Between the $C$. variolosus groups high differences in these scores occur, the highest within species value was 2.85 between central-east and the western populations of the Southern Carpathian Arc. Only small glaciers covered the Carpathian Mts during the ice age period, except a bigger one on the Fagaras Mts and another one in the northern parts (Theowald \& Mannheims 1962), the former isolated the western populations form those in more eastern regions for a more extended period.

The differences between $C$. variolosus and C. nodulosus ranged from $<1.0 \%$ to $5.4 \%$, with the highest values between geographically close populations. Calibration of a time scale was performed using the rate published by ANDUJAR et al. (2012) that was based on various Carabus species of diverse subgenera $(2.26 \% / \mathrm{my})$. This is a rate comparable to the standard for insects (BROwER 1994). Papadopoulou et al. (2010) discussed the problems of rate calibration in detail and documented high variation in published rates. They got a rate of 3.36 or 3.54 , respectively, calibrating their data on tenebrionid beetles by the Mid-Aegean trench.

ITS2 substitution rates were much lower than those of the mitochondrial genes (1.14\%/my, AnduJAR et al. 2012). Applying this to the 3.5\% ITS2 distance between $C$. variolosus and $C$. nodulosus, the split between them occurred 3.07 myBP. A partial branch with more or less constant values had a mean distance of 5.2, and a single maximum was 6.3 in another branch. This is an indication for an early split.

In another EU protected species, the cerambycid Morimus funereus, the ITS2 data show only a 7-position gap between two haplotype groups and hybrids also occur (Solano et al. 2013). At the other hand, Audisio et al. (2009) found high ITS2 distances (mean 4.4-18.6\%) between Osmoderma spp., another Annex II taxon, the data of which are unfortunately not available in GenBank.

At first sight, our data suggest a lower evolutionary rate in COI-3' than in COI-5'. We found a higher diversity in the latter gene part in the same specimens. A much earlier split of $C$. variolosus and $C$. nodulosus was the result when considering ITS2 data. In consequence, the split must be dated between 1-3 myBP. The most probable date seemed to be that indicated by COI- $5^{\prime}$.

In plant ITS2 data, CBC indicate different species with high certainty (Seibel et al. 2006). We found neither CBCs in our data nor those of the Carabus subgenus Chrysocarabus (data used from DürING et al. 2001) but given that 
very few data exist on insects, we cannot conclude that this indicates that the two taxa are subspecies.

\section{High variability}

Both Hygrocarabus taxa show low or very low morphological variability and only a few small differences could be found to establish their separate species status, except the form of the aedeagus' tip (CASALE et al. 1982).

Carabus nodulosus colonised Central Europe after the last glaciation from a refuge, located southeast of the Alps. Such a low variability is an indication for a fast recolonisation, a phenomenon also found in Carabus intricatus (PrüsER 1996) and Abax parallelepipedus (DürING 2004) in Central Europe and Cychrus caraboides in Scandinavia (Düring \& MossaKowsKi 1995).

MATERn et al. (2010) found a very low sequence variability of COI-3' in their $C$. nodulosus populations. That was the consequence of the regions under study, which cover mainly the areas of postglacial recolonisation (our HTP3 and partly HTP2).

\section{Refuges}

For a long period, the discussion on refuges during the Pleistocene was dominated by the paradigm of Mediterranean refuges, first based on morphological and biogeographical (e. g. compilation by De Latтin 1967), later on, molecular data (HewitT 1996, 2000, TABerlet 1998). The three sample cases are the grasshopper (Balkan Peninsula), the hedgehog (all three peninsulas) and the brown bear (E and $\mathrm{W})$. With the growing evidence for refuges north of the Mediterranean area, STEWART et al. (2010) suggested the existence of cryptic refuges.

However, concepts of refuges existed long before the modern debate (Drees et al. 2010). Holdhaus and Lindroth (1939) are the pioneers in this field, and they pointed to the Holdhaus line (Holdhaus 1954) that describes a northern limit of the European occurrence of blind edaphic and troglobiotic beetles. There are three refuges south of the Holdhaus line for Carabus auronitens and possibly others north of it (Drees et al. 2010). Homburg et al. (2013) found refuges north of the Holdhaus line in a study on Carabus irregularis in the eastern and the southern Carpathian Arc, but they did not analyse material from the westernmost part of the southern arc. 
We hypothesise several refuges for both taxa:

C. nodulosus

- $\quad$ SE edge of the Alps (haplotype group (HTG 1); the starting point of migration to the North and West (HTG 2, 3);

- $\quad$ E Slovenia, N Croatia (HTG 4);

- $\quad$ S Balkan Peninsula (HTG 6); migration into the C. variolosus area and introgression into C. variolosus;

Unknown; introgression into C. variolosus (HTG 5).

C. variolosus

- Western part of S Carpathian Mts (нтG W);

- SE part of Carpathian Mts (HTG SE);

- Central and northern part of Carpathian Mts? (HTG CN);

- Separate refuge in the Sighisoara region? (HTG CE).

The different haplotype groups in C. variolosus show a pattern of at least three separated regions that we interpret as refuges: the western part of the southern Carpathian Mts, the SE of the Romanian Carpathian Arc, and a Romanian north-central area. The early split of beetles from Sighisoara may indicate an additional one that must be corroborated. It is striking that $C$. variolosus

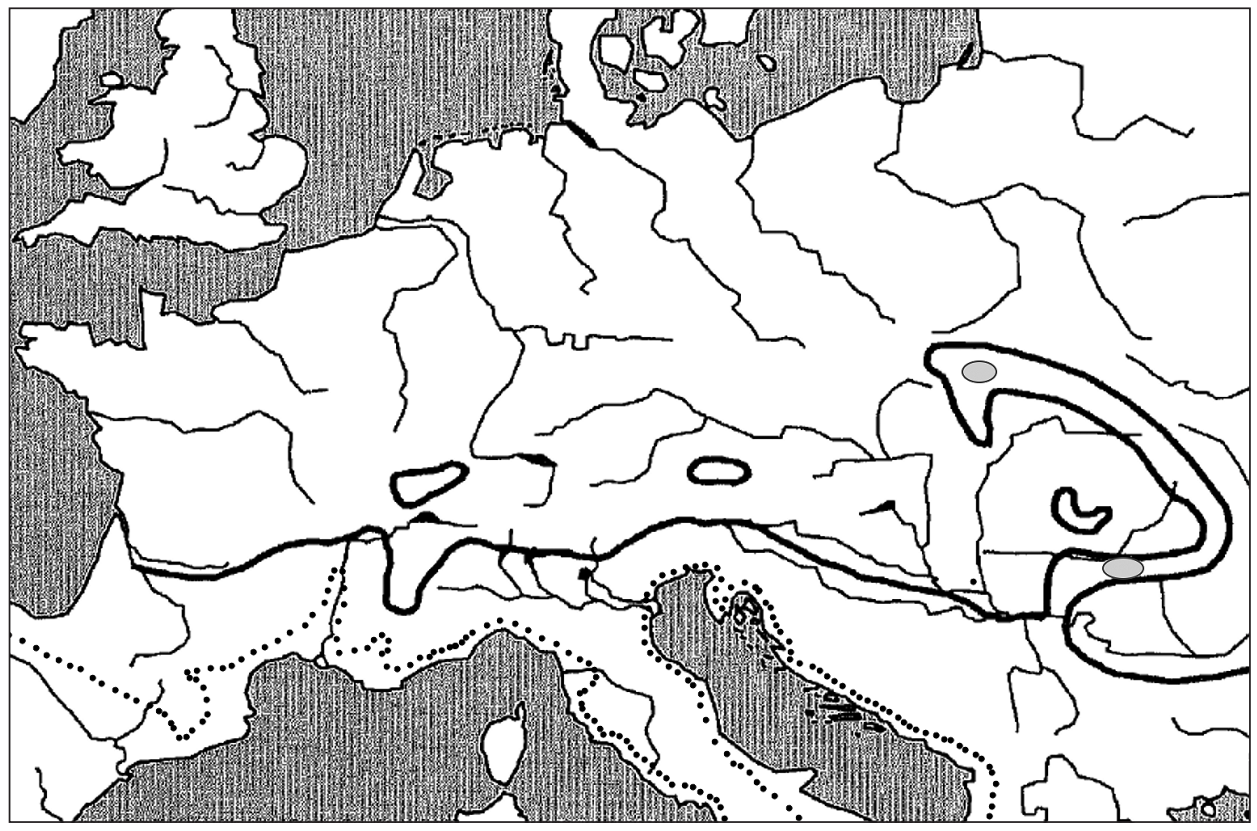

Fig. 6. Holdhaus line (black) and the northern limits of garigue and macchia vegetation (dotted). Based on Drees et al. (2010), line of northern garrigue and macchia limits from CADENAS (2020), and two glaciers in the Carpathians from Theowald and Mannheims (1962) 
did not expand markedly after the last glaciation except along the mountain arc to the north to the Sudeten Mts. The reason for this may be its low power of dispersal. On the other hand, $C$. variolosus can be found down to the foothill of lower mountains where alder (Alnus glutinosa) trees occur, but not on the plains at the foot of the mountain.

It is not sufficient to divide refuges into Mediterranean and cryptic ones. Additional ecological aspects should complement this geographical aspect.

A zone of moderate Mediterranean climate can be distinguished between the Holdhaus line and the region with more extreme conditions indicated by the occurrence of garigue and macchia vegetation (Fig. 6).

The hypothesised refuges for both Hygrocarabus taxa showed a position in this moderate Mediterranean zone.

\section{CONCLUSIONS}

We started with the hypothesis that the taxa C. variolosus and C. nodulosus are subspecies, as this was the common viewpoint in the literature (MüLLERKroehling 2006). The data of mitochondrial genes and the occurrence of hybrids between the taxa under study seemed to corroborate that. Nevertheless, three arguments contradicted this hypothesis: (i) no mating attempts between the two taxa; (ii) The ITS2 data between both taxa showed remarkable differences that were comparable with those between species of three other Carabus subgenera that include well-established species; (iii) At first glance, the detection of hybrids between $C$. variolosus and C. nodulosus seems to be an argument for subspecies status. However, the high number of differences of these groups against other $C$. variolosus as well $C$. nodulosus must be interpreted as the consequence of an early hybridisation introgression, relatively close in time to the basal split of the taxa.

Although these three arguments are supporting the species status, it is necessary to complement our study by additional crossbreeding experiments with specimens from other locations and by sequence data in particular from Slovakia, the southern Balkan and the Carpathian Basin in order to get a better insight into regions where early splits happened.

Although the taxa differ sparsely in morphology, the sequence data show high diversity. A relatively uniform morphology may be interpreted as a consequence of the extreme adaptation of their common ancestor to life under water.

A series of refuges existed during the ice ages southeast of the Alps, on the Balkan Peninsula and in the Carpathian region. All are located south of the Holdhaus line in a region with a moderate Mediterranean climate north or above the garrigue or macchia vegetation. 
Although only the taxon C. variolosus is listed in Annex II and IV of the EU habitats directive, the results reported here do not put in question the general consensus that $C$. nodulosus also falls under this listing, as at the time of amendment of the Annexes to include the species in 2004, the majority of sources treated both taxa as subspecies (MülLER-Kroehling 2006), and hence the listing would include both, independent of later taxonomic revisions, very much like the situation in Osmoderma eremita, which is now split into five different species, and which all are Osmoderma eremita sensu the Habitats Directive (Audisio et al. 2009). Hence, no matter how the taxonomic decision finally turns out, both should be considered as Annex Species of the Habitats Directive (MülLER-Kroehling et al. 2019).

$*$

Acknowledgements - We cordially thank the following colleagues for helpful comments, loaning or sending of specimens, and the DNA sequence analyses: Carmelo Andujar, Michael Balke, Ortwin Bleich, Andreja Brigic, Achille Casale, Srecko Curcic, Wolfgang Dormann, Roland Gerstmeier, Borislav Gueorguiev, Jirí Hajek, Radek Janák, Karsten Hannig, Lucija Serica-Jelaska, Victor Krochko, Andrea Matern, Gábor Mészáros, Ruslan Panin, Johannes Schied, Harald Schillhammer, Thomas Schmidt (HH), Tomasz Skalski, Győző Szél, Ingo Wolff, Manfred Zeising, Marco Zimmermann, and the team of Advanced Identification Methods. Special thanks to Andrea Matern who gave her unpublished sequence data to D.M. We are grateful to the anonymous reviewers for their comments made it possible to make the manuscript more rigorous.

\section{REFERENCES}

Allemand, R. \& Malausa, J.-C. (1984): Compatibilité génétique et distance phylétique entre les espèces du genre Chrysocarabus Thomson (Col., Carabidae). - Annales de la Sociéte Entomologiques de France (N.S.) 20: 347-363.

Altschul, S. F., Gish, W., Miller, W., Myers, E. W. \& Lipman, D. J. (1990): Basic local alignment search tool. - Journal of Molecular Biology 215: 403-410. https://doi.org/10.1016/ S0022-2836(05)80360-2

Andujar, C., Gomez-Zurita J., Rasplus, J.-Y. \& Serrano, J. (2012): Molecular systematics and evolution of the subgenus Mesocarabus Thomson, 1875 (Coleoptera: Carabidae: Carabus), based on mitochondrial and nuclear DNA. - Zoological Journal of the Linnean Society 166: 787-804. https://doi.org/10.1111/j.1096-3642.2012.00866.x

Andújar, C., Serrano, J. \& Gómez-Zurita, J. (2012): Winding up the molecular clock in the genus Carabus (Coleoptera: Carabidae): assessment of methodological decisions on rate and node age estimation. - BMC Evolutionary Biology 12(1): 40. https://doi. org/10.1186/1471-2148-12-40

Audisio, P., Brustel, H., Carpaneto, G. M., Coletti, G., Mancini, E., Trizzino, M., AnTONINI, G. \& DE BiAse, A. (2009): Data on molecular taxonomy and genetic diversification of the European Hermit beetles, a species-complex of endangered insects (Coleoptera: Scarabaeidae, Cetoniinae, Osmoderma). - Journal of Zoological Systematics and Evolutionary Research 47: 88-95 https://doi.org/10.1111/j.1439-0469.2008.00475.x 
Breuning, S. (1926): Über Carabus variolosus Fabr. - Koleopterologische Rundschau 12: 19-25. BŘezina, B., Huber, C. \& Marggi, W. (2017): Subtribe Carabina. - Pp. 70-207. In: LöBl, I. \& Löвl, D. (eds): Catalogue of Palaearctic Coleoptera. Revised and Updated Edition, Vol. 1, Archostemata-Myxophaga-Adephaga. - Brill, Leiden, Boston,

BRower, A. V. Z. (1994): Rapid morphological radiation and convergence among races of the butterfly Heliconius erato inferred from patterns of mitochondrial DNA evolution. - Proceedings of the National Academy of Science U.S.A. 91: 6491-6495. https://doi. org/10.1073/pnas.91.14.6491

Cadenas, F. (2012): El paisatge vegetal de clima mediterrani. https://francadenas.blogspot. com/2012/11/el-paisatge-vegetal-de-clima-mediterrani.html

Casale, A., Sturani, M. \& Vigna Taglianti, A. (1982): Fauna d'Italia - Carabidae I - Introduzione, Paussinae, Carabinae. - Edizione Calderini, Bologna, 499 pp.

Chromas (2008): Chromas 2.33. - http://technelysium.com.au/wp/chromas/

Curcic, S. \& Stankovic, M. (2011): The ground beetles (Coleoptera: Carabidae) of the Zasavica special nature reserve (Serbia). - Acta entomologica serbica 16(1-2): 61-79.

De Lattin, G. (1967): Grundriss der Zoogeographie. - G. Fischer, Stuttgart, 602 pp.

Deuve, T. (2004): Illustrated catalogue of the genus Carabus of the world (Coleoptera: Carabidae). - Pensoft, Sofia-Moscow, 461 pp.

Deuve, T. (2019): Classification du genre Carabus L., 1758. - Liste Blumenthal 2018-2019 (Coleoptera, Carabidae). - Coléoptères 25(5): 33-102.

Dobzhansky, T. (1970): Genetics of the evolutionary process. - Columbia University Press. Cited from MaYden.

Drees, C., Matern, A., von Oheimb, G., Reimann, T. \& Assmann, T. (2010): Multiple glacial refuges of unwinged ground beetles in Europe: Molecular data support classical phylogeographic models. Pp. 253-265. In: Habel, J. C. \& Assmann, T. (eds): Relict species. Phylogeography and conservation biology. - Springer, Berlin, Heidelberg. https:// doi.org/10.1007/978-3-540-92160-8_14

DüRING, A. \& Mossakowski, D. (1995): Geographische Variation der mitochondrialen DNA bei Cychrus caraboides (Linné, 1758). - Mitteilungen der deutschen Gesellschaft für allgemeine und angewandte Entomologie 10: 401-406.

DürING, A. (2004) Molekularsystematische Untersuchungen am Carabidentaxon Abax Bonelli, 1810 (Coleoptera, Carabidae). Eine phylogenetische und phylogeographische Studie. - Verlagsgruppe Mainz $\mathrm{GmbH}$, Aachen, $363 \mathrm{pp}$.

Düring, A., Brückner, M., Zimmermann, M., Bobenhausen, I., Eicke, N. \& Mossakowski, D. (2000): Geographic distribution of two highly different mtDNA haplotypes in Carabus (Chrysocarabus) splendens Olivier. Pp. 5-9. In: Brandmayr, P., Lövei, G. L., Zetto Brandmayr, T., Casale, A. \& Vigna Taglianti, A. (eds): Natural history and applied ecology of carabid beetles. - Pensoft, Sofia.

DÜRING, A., BRÜCKNER, M. \& MossAKowsKI, D. (2006): Different behaviour of mitochondrial and nuclear markers: Introgression and the evolutionary history of Chrysocarabus. Entomologica Fennica 17: 200-206. https://doi.org/10.33338/ef.84330

Felsenstein, J. (1984): Confidence limits on phylogenies: An approach using the bootstrap. - Evolution 39(4): 783-791. https://doi.org/10.1111/j.1558-5646.1985.tb00420.x

Fourment, M. \& Holmes E. C. (2016): Seqotron: a user-friendly sequence editor for Mac OS X. - BMC Research Notes 17; 9(1): 106. https://doi.org/10.1186/s13104-016-1927-4

Guéorguiev, V. B. \& Guéorguiev, B. V. (1995): Catalogue of the ground-beetles of Bulgaria (Coleoptera: Carabidae). - Pensoft Publishers, Sofia-Moscow, 279 pp. 
Hewitt, G. M. (1996): Some genetic consequences of ice ages, and their role in divergence and speciation. - Biological Journal of the Linnean Society 58: 247-276. https://doi. org/10.1006/bijl.1996.0035

HewitT, G. M. (2000): The genetic legacy of the Quaternary ice ages. - Nature 405: 907-913. https://doi.org/10.1038/35016000

Holdhaus, K. (1954): Die Spuren der Eiszeit in der Tierwelt Europas. - Abhandlungen der zoologisch-botanischen Gesellschaft Wien 18: 1-493.

Holdhaus, K. \& Lindroth, C. H. (1939): Die europäischen Coleopteren mit boreoalpiner Verbreitung. - Naturhistorisches Museum Wien, Wien. https://www.biologiezentrum.at

Homburg, K., Drees, C., Gossner, M. M., Rákosy, L., Vrezec, A. \& Assmann, T. (2013): Multiple glacial refugia of the low-dispersal ground beetle Carabus irregularis: molecular data support predictions of species distribution models. - PLoS One 8(4): e61185. https://doi.org/10.1371/journal.pone.0061185

Котн, W. (1974): Vergesellschaftungen von Carabiden (Col., Ins.) bodennasser Habitate des Arnsberger Waldes verglichen mit Hilfe der Renkonenzahl. - Abhandlungen des westfälischen Museums für Naturkunde 36: 1-43.

Kuhlemann, J., Dobre, F., Urdea, P., Krumrei, I., Gachev, E., KubiK, P. \& Rahn, M. (2013): Last Glacial Maximum glaciation of the central South Carpathian range (Romania). Austrian Journal of Earth Sciences Vienna 106(2): 50-62.

Kumar, S., Stecher, G., Li, M., Knyaz, C. \& Tamura, K. (2018): MEGA X: Molecular Evolutionary Genetics Analysis across computing platforms. - Molecular Biology and Evolution 35: 1547-1549. https://doi.org/10.1093/molbev/msy096

Lassalle, B. \& Renaut, P. (2008): Reproduction en captivité de Carabus (Hygrocarabus) nodulosus Creutzer (Coleoptera, Carabidae). - Le Coléoptériste 11(2): 116-119.

Lorenz, W. (2019): CarabCat: Global database of ground beetles (version Oct 2017). - In: Roskov, Y., Ower, G., Orrell, T., Nicolson, D., Bailly, N., Kirk, P. M., Bourgoin, T., DeWalt, R. E., Decock, W., Nieukerken, E. van, Zarucchi, J. \& Penev, L. (eds): Species 2000 E ITIS Catalogue of Life, 2019 Annual Checklist. Digital resource at www. catalogueoflife.org/annual-checklist/2019. Species 2000: Naturalis, Leiden, the Netherlands.

Matern, A., Drees, C., Meyer, H. \& Assmann, T. (2008): Population ecology of the rare carabid beetle Carabus variolosus (Coleoptera: Carabidae) in north-west Germany. Journal of Insect Conservation 12(6): 591-601. https://doi.org/10.1007/s10841-007-9096-3

Matern, A., Drees, C., Vogler, A. P. \& Assmann, T. (2010): Linking genetics and ecology: Reconstructing the history of relict populations of an endangered semi-aquatic species. - Pp. 253-265. In: Habel, J. C. \& Assmann, T. (eds): Relict species. Phylogeography and conservation biology. - Springer, Berlin, Heidelberg. https://doi.org/10.1007/978-3540-92160-8_14

MAyden, L. (1997). A hierarchy of species concepts: the denouement in the saga of the species problem. - Pp. 381-424. In: Claridge, M. F., Dawah, H. A. \& Wilson, M. R. (eds): Species - The units of biodiversity. - Chapman \& Hall, London.

Mossaкоwsкi, D. (2016): Introgression or low molecular differentiation? The case of Carabus maacki. - Periodicum Biologorum 118(3): 299-306. https://doi.org/10.18054/ pb.2016.118.3.3922

Müller-Kroehling, S. (2006): Ist der Gruben-Großlaufkäfer Carabus (variolosus) nodulosus ein Taxon des Anhanges II der FFH-Richtlinie in Deuschland? - Waldökologie Online 3: 57-62. 
Müller-Kroenling, S. (2014): Remarks on the current situation of Carabus variolosus nodulosus relating to the interpretation of its Habitats Directive status, the 2013 report under that directive, and its threat level in Germany and Central Europe - Angewandte Carabidologie 10: 97-100.

Müller-Kroehling, S., Adelmann, W., Ssymank, A. \& Ellwanger, G. (2019): Art oder Unterart? Der Grubenlaufkäfer ist in jeder Hinsicht eine Fauna-Flora-Habitat-Art. - Anliegen Natur 41 (1): 193-198.

Nagata, N., Kuвota, K. \& Sota, T. (2007): Phylogeography and introgressive hybridization of the ground beetle Carabus yamato in Japan based on mitochondrial gene sequences. - Zoological Science 24(5): 465-474. https://doi.org/10.2108/zsj.24.465

Papadopoulou, A., Anastasiou, I. \& Vogler, A. P. (2010): Revisiting the insect mitochondrial molecular clock: The Mid-Aegean Trench calibration. - Molecular Biology and Evolution 27(7): 1659-1672. https://doi.org/10.1093/molbev/msq051

Pentinsaari, M., Hebert, P. D. N. \& Mutanen, M. (2014): Barcoding beetles: A regional survey of 1872 species reveals high identification success and unusually deep interspecific divergences. - PLoS One e108651 https://doi.org/10.1371/journal.pone.0108651

PRÜSER, F. (1996): Variabilität mitochondrialer DNA-Sequenzen und die Phylogenie der Gattung Carabus Linné, 1758 (Coleoptera: Carabidae). - Dissertation, Universität Bremen, 173 pp.

Puisségur, C. (1964): Recherches sur la génétique des Carabes. - Vie et Milieu, Suppl. 18: 1-288.

Rasplus, J.-Y., Meusnier, S., Mondor, G., Piry, S. \& Cornuet, J.-M. (2000): Microsatellite analysis of genetic population structure in the endangered beetles: Carabus solieri (Carabidae). - Pp. 11-24. In: Brandmayr, P., Lövei, G., Zetto-Brandmayr, T., Casale, A. \& Vigna Taglianti, A. (eds): Natural history and applied ecology of carabid beetles. Proc. 9th European Carabid. Meeting, Cosenza 1998. - Pensoft Publishers, SofiaMoscow.

Raupach, M. J., Astrin, J. J., Hannig, K., Peters, M. K., Stoeckle, M. Y. \& Wägele, J. W. (2010): Molecular species identifications of Central European ground beetles (Coleoptera: Carabidae) using nuclear rDNA expansion segments and DNA barcodes. - Frontiers in Zoology 7: 26. https://doi.org/10.1186/1742-9994-7-26

Raupach, M. J., Hannig, K., Morinière, J. \& Hendrich, L. (2018): A DNA barcode library for ground beetles of Germany: the genus Amara Bonelli, 1810 (Insecta, Coleoptera, Carabidae). - ZooKeys 759: 57-80. https://doi.org/10.3897/zookeys.759.24129

Reimann, T., Assmann, T., Nolte, O., Reuter, H., Huber, C. \& Weber, F. (2002): Palaeogeography and palaeoecology of Carabus auronitens (Coleoptera): characterisation and localisation of glacial refugia in Southern France and reconstruction of postglacial expansion routes by means of allozyme polymorphism. - Abhandlungen des Narturwissenschaftlichen Vereins zu Hamburg (NF) 35: 1-151.

Seibel, P. N., Müller, T., Dandekar, T., Schultz, J. \& Wolf, M. (2006): 4SAlE - A tool for synchronous RNA sequence and secondary structure alignment and editing. - BMC Bioinformatics 7: 498. https://doi.org/10.1186/1471-2105-7-498

Solano, E., Mancini, E., Ciucci, P., Mason, F., Audisio, P. \& Antonini, G. (2013): The EU protected taxon Morimus funereus Mulsant, 1862 (Coleoptera: Cerambycidae) and its western Palaearctic allies: systematics and conservation outcomes. - Conservation Genetics 14: 683-694. https://doi.org/10.1007/s10592-013-0461-3

Sota, T., Ishikawa, R., Ujiıe, M., Kusumoto, F. \& Vogler, A. P. (2001): Extensive transspecies mitochondrial polymorphisms in the carabid beetles Carabus subgenus Ohomopterus caused by repeated introgressive hybridisation. - Molecular Ecology 10: 2833-2847. https://doi.org/10.1046/j.1365-294X.2001.t01-1-01404.x 
Sota, T. \& Vogler, A. P. (2001): Incongruence of mitochondrial and nuclear gene trees in the Carabid beetles Ohomopterus. - Systematic Biology 50(1): 39-59. https://doi. org/10.1080/106351501750107459

Sota, T., Kusumoto, F. \& Кивота, K. (2000): Consequences of hybridisation between Ohomopterus insulicola and O. arrowianus (Coleoptera, Carabidae) in a segmented river basin: parallel formation of hybrid swarms. - Biological Journal of the Linnean Society 71: 297-313. https://doi.org/10.1006/bij1.2000.0444

Stecher, G., Tamura, K. \& Kumar, S. (2020): Molecular Evolutionary Genetics Analysis (MEGA) for macOS. - Molecular Biology and Evolution 37(4): 1237-1239. https://doi. org $/ 10.1093 / \mathrm{molbev} / \mathrm{msz} 312$

Streiff, R., Veyrier, R., Audiot, P., Meusnier, S. \& Brouat, C. (2005): Introgression in natural populations of bioindicators: a case study of Carabus splendens and Carabus punctatoauratus. - Molecular Ecology 14: 3775-3786. https://doi.org/10.1111/j.1365294X.2005.02714.x

Sturani, M. (1962): Observazioni e ricerche biologiche sul genere Carabus (sensu lato) (Coleoptera Carabidae). - Memorie della Societa Entomologica Italiana 41: 85-203.

Sturani, M. (1963): Nuevo ricerche biologiche sul Carabus (Hygrocarabus) variolosus Fabr. (Coleoptera Carabidae). - Bollettino di zoologia agraria e di Bachicoltura S II: 25-34.

Szél, G., RetezÁr, I., BérCes, S., FüLöp, D., SzABó, K. \& Pénzes, Z. (2008): Magyarország futrinkái. [Carabus species of Hungary]. - Pp. 81-106. In: Forró, L. (ed.): A Kárpát-medence állattani értékei és faunájának kialakulása. Magyar Természettudományi Múzeum, Budapest.

Tallósi, B. \& Mesaroš, G. (2020): Podaci o rasprostranjenju vrste Carabus variolosus Fabricius, 1787 u Srbiji. Portal za kartiranje biološke raznovrsnosti Srbije. - BioRas. Preuzeto 19.08.2020 sa stranice.

Taberlet, P., Fumagalli, L., Wust-Sauci, A.-G. \& Cosson, J.-F. (1998): Comparative phylogeography and postglacial colonisation routes in Europe. - Molecular Ecology 7: 453-464. https://doi.org/10.1046/j.1365-294x.1998.00289.x

Theowald, B. \& Mannheims, B. (1962): Die Arten der Tipula (Vestiplex) excisa-Gruppe in der Paläarktis. - Bonner zoologische Beiträge 13(4): 360-402.

Turin, H., Penev, L., Casale, A., Arndt, E., Assman, T., Makarov, K., Mossakowski, D., Szél, G. \& Weber, F. (2003): Species accounts. - Pp. 151-283. In: Turin, H., Penev, L. \& Casale, A. (eds): The genus Carabus in Europe. A synthesis. - Pensoft, Sofia-Moscow.

Ujui, M., KuвотA, K., Sota, T. \& Ishiкawa, R. (2005): Parallel formation of hybrid swarms of ground beetles in the genus Carabus (Coleoptera: Carabidae) in adjacent river basins. - Entomological Science 8: 429-437. https://doi.org/10.1111/j.1479-8298.2005.00142.x

Vrezec, A., Polak, S., Kapla, A., Pirnat, A., Grobelnik, V. \& Šalamun, A. (2007): Monitoring populacij izbranih ciljnih vrst hroščev - Carabus variolosus, Leptodirus hochenwartii, Lucanus cervus in Morinus funereus, Rosalia alpina. - Nacionalni inštitut za biologijo, Ljubljana, 288 pp.

Zhang, A.-B., Kubota, K., TакAmi, Y., Kiм, J. L., Kim, J. K. \& Sota, T. (2005): Species status and phylogeography of two closely related Coptolabrus species (Coleoptera: Carabidae) in South Korea inferred from mitochondrial and nuclear gene sequences. - Molecular Ecology 14: 3823-3841. https://doi.org/10.1111/j.1365-294X.2005.02705.x

Zhang, A. B. \& Sota, T. (2007): Nuclear gene sequences resolve species phylogeny and mitochondrial introgression in Leptocarabus beetles showing trans-species polymorphisms. - Molecular Phylogenetics and Evolution 45: 534-546. https://doi.org/10.1016/j. ympev.2007.07.003

Received September 5, 2020, accepted December 15, 2020, published December 28, 2020 
Appendix 1. Material of Carabus variolosus and C. nodulosus used for the analyses. CC = Country Code

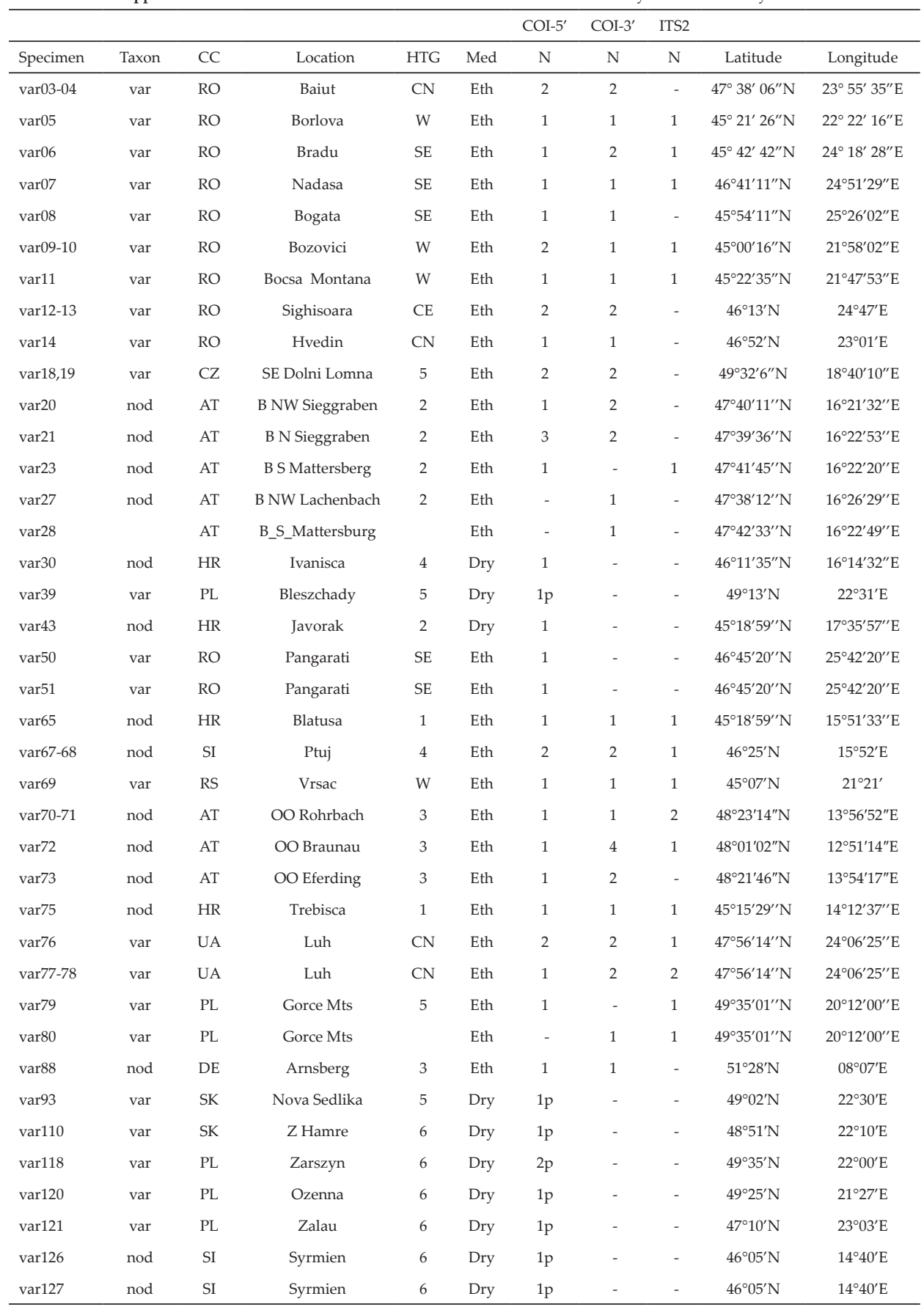




\begin{tabular}{|c|c|c|c|c|c|c|c|c|c|c|}
\hline & & & & & & COI-5' & COI-3' & ITS2 & & \\
\hline Specimen & Taxon & $\mathrm{CC}$ & Location & HTG & Med & $\mathrm{N}$ & $\mathrm{N}$ & $\mathrm{N}$ & Latitude & Longitude \\
\hline var128 & nod & SI & Zavratnik & 6 & Dry & $1 \mathrm{p}$ & - & - & $46^{\circ} 22^{\prime} \mathrm{N}$ & $14^{\circ} 45^{\prime} \mathrm{E}$ \\
\hline var136 & nod & SI & Krakovsk Godz & 1 & Dry & 2 & 4 & 2 & $45^{\circ} 49^{\prime} \mathrm{N}$ & $15^{\circ} 10^{\prime} \mathrm{E}$ \\
\hline var139 & nod & SI & Krakovsk Godz & 1 & Dry & $1 \mathrm{p}$ & 1 & - & $45^{\circ} 49^{\prime} \mathrm{N}$ & $15^{\circ} 10^{\prime} \mathrm{E}$ \\
\hline var150 & nod & SI & Rodik & 6 & Dry & $1 \mathrm{p}$ & - & - & $45^{\circ} 37^{\prime} 29^{\prime \prime} \mathrm{N}$ & $13^{\circ} 58^{\prime} 53^{\prime \prime}$ \\
\hline var151 & nod & SI & Harije & 6 & Dry & $1 p$ & 1 & - & $45^{\circ} 33^{\prime} \mathrm{N}$ & $14^{\circ} 11^{\prime} \mathrm{E}$ \\
\hline var153 & nod & SI & Vrbace & 6 & Dry & $2 \mathrm{p}$ & - & - & $45^{\circ} 46^{\prime} \mathrm{N}$ & $13^{\circ} 57^{\prime} \mathrm{E}$ \\
\hline var158 & nod & BA & Vares & 6 & Dry & $1 \mathrm{p}$ & - & - & $44^{\circ} 09^{\prime} \mathrm{N}$ & $18^{\circ} 19^{\prime} \mathrm{E}$ \\
\hline var164 & nod & $\mathrm{HR}$ & Srednji & 6 & Dry & 1 & 1 & - & $45^{\circ} 15^{\prime} \mathrm{N}$ & $17^{\circ} 22^{\prime} \mathrm{E}$ \\
\hline var165 & nod & HR & Srednji & 6 & Dry & $1 \mathrm{p}$ & - & - & $45^{\circ} 15^{\prime} \mathrm{N}$ & $17^{\circ} 22^{\prime} \mathrm{E}$ \\
\hline var168 & nod & IT & Taipana & 1 & Eth & 2 & 2 & 2 & $46^{\circ} 15^{\prime} \mathrm{N}$ & $13^{\circ} 20^{\prime} \mathrm{E}$ \\
\hline var170-73 & nod & AT & ST S Graz Unterpr. & 2 & Eth & 4 & 3 & 3 & $46^{\circ} 57^{\prime} 58^{\prime \prime} \mathrm{N}$ & $15^{\circ} 23^{\prime} 10^{\prime \prime} \mathrm{E}$ \\
\hline var174-77 & nod & AT & K SW Tainach & 2 & Eth & 4 & 4 & 3 & $46^{\circ} 38^{\prime} 35^{\prime \prime} \mathrm{N}$ & $14^{\circ} 32^{\prime} 59^{\prime \prime} \mathrm{E}$ \\
\hline var180 & nod & BA & Jablanica & 6 & Dry & $1 \mathrm{p}$ & - & - & $43^{\circ} 39^{\prime} \mathrm{N}$ & $17^{\circ} 45^{\prime} \mathrm{E}$ \\
\hline var185 & nod & AT & K W Meiernigg & 2 & Eth & 2 & 2 & - & $46^{\circ} 36^{\prime} 34^{\prime \prime} \mathrm{N}$ & $14^{\circ} 15^{\prime} 05^{\prime \prime} \mathrm{E}$ \\
\hline var188-89 & nod & $\mathrm{AT}$ & St_E-Arnfels & 2 & Eth & 2 & 2 & - & $46^{\circ} 39^{\prime} 17^{\prime \prime} \mathrm{N}$ & $15^{\circ} 31^{\prime} 10^{\prime \prime} \mathrm{E}$ \\
\hline var191-92 & nod & AT & ST S Graz Raaba & 2 & Eth & 2 & 2 & - & $47^{\circ} 02^{\prime} 08^{\prime \prime} \mathrm{N}$ & $15^{\circ} 30^{\prime} 38^{\prime \prime} \mathrm{E}$ \\
\hline var193 & nod & AT & ST S Graz Raaba & 3 & Eth & 1 & - & - & $47^{\circ} 02^{\prime} 08^{\prime \prime} \mathrm{N}$ & $15^{\circ} 30^{\prime} 38^{\prime \prime} \mathrm{E}$ \\
\hline var194-95 & nod & DE & Traunstein & 3 & Eth & 1 & 1 & - & $47^{\circ} 49^{\prime} 47^{\prime \prime} \mathrm{N}$ & $12^{\circ} 30^{\prime} 04^{\prime \prime} \mathrm{E}$ \\
\hline var197 & nod & $\mathrm{HU}$ & W Csesznek & 2 & Eth & 1 & 1 & - & $47^{\circ} 20^{\prime} 08^{\prime \prime} \mathrm{N}$ & $17^{\circ} 50^{\prime} 22^{\prime \prime} \mathrm{E}$ \\
\hline var198 & var & $\mathrm{RO}$ & Bradu & SE & Eth & 1 & - & - & $45^{\circ} 42^{\prime} 42^{\prime \prime} \mathrm{N}$ & $24^{\circ} 18^{\prime} 28^{\prime \prime} \mathrm{E}$ \\
\hline var199 & var & $\mathrm{RO}$ & Reghin & SE & Eth & 1 & 1 & 1 & $46^{\circ} 45^{\prime} 17^{\prime \prime} \mathrm{N}$ & $24^{\circ} 43^{\prime} 40^{\prime \prime} \mathrm{E}$ \\
\hline var200 & var & $\mathrm{RO}$ & Clit & $\mathrm{CN}$ & Eth & 2 & 3 & - & $47^{\circ} 17^{\prime} 13^{\prime \prime} \mathrm{N}$ & $23^{\circ} 24^{\prime} 31^{\prime \prime} \mathrm{E}$ \\
\hline var201-02 & var & $\mathrm{RO}$ & Clit & $\mathrm{CN}$ & Eth & 1 & 1 & 2 & $47^{\circ} 17^{\prime} 13^{\prime \prime} \mathrm{N}$ & $23^{\circ} 24^{\prime} 31^{\prime \prime} \mathrm{E}$ \\
\hline var203 & var & $\mathrm{RO}$ & Clit & $\mathrm{CN}$ & Eth & 1 & - & - & $47^{\circ} 17^{\prime} 13^{\prime \prime} \mathrm{N}$ & $23^{\circ} 24^{\prime} 31^{\prime \prime} \mathrm{E}$ \\
\hline var204-6 & var & $\mathrm{CZ}$ & Jesenik & 5 & Eth & 3 & 3 & - & $50^{\circ} 12^{\prime} 54^{\prime \prime} \mathrm{N}$ & $17^{\circ} 17^{\prime} 55^{\prime \prime} \mathrm{E}$ \\
\hline var213 & var & UA & Luh & $\mathrm{CN}$ & Eth & 1 & - & 1 & $47^{\circ} 56^{\prime} 14^{\prime \prime} \mathrm{N}$ & $24^{\circ} 06^{\prime} 25^{\prime \prime} \mathrm{E}$ \\
\hline var214-15 & var & UA & Luh & 5 & Eth & 2 & 2 & 2 & $47^{\circ} 56^{\prime} 14^{\prime \prime} \mathrm{N}$ & $24^{\circ} 06^{\prime} 25^{\prime \prime} \mathrm{E}$ \\
\hline var216 & var & $\mathrm{CZ}$ & Jesenik & $\mathrm{CN}$ & Eth & 1 & 2 & 5 & $50^{\circ} 12^{\prime} 54^{\prime \prime} \mathrm{N}$ & $17^{\circ} 17^{\prime} 55^{\prime \prime} \mathrm{E}$ \\
\hline var217 & var & $\mathrm{CZ}$ & Jesenik & $\mathrm{CN}$ & Eth & 1 & 1 & - & $50^{\circ} 12^{\prime} 54^{\prime \prime} \mathrm{N}$ & $17^{\circ} 17^{\prime} 55^{\prime \prime} \mathrm{E}$ \\
\hline var218 & var & $\mathrm{CZ}$ & Jesenik & $\mathrm{CN}$ & Eth & 1 & 1 & - & $50^{\circ} 12^{\prime} 54^{\prime \prime} \mathrm{N}$ & $17^{\circ} 17^{\prime} 55^{\prime \prime} \mathrm{E}$ \\
\hline var219 & var & $\mathrm{HU}$ & NE Zemplen & 5 & Dry & 1 & 1 & 1 & $48^{\circ} 25^{\prime} 50^{\prime \prime} \mathrm{N}$ & $21^{\circ} 24^{\prime} 59^{\prime \prime} \mathrm{E}$ \\
\hline var220 & nod & $\mathrm{HU}$ & W Rede & 2 & Eth & 1 & 2 & 1 & $47^{\circ} 22^{\prime} 52^{\prime \prime} \mathrm{N}$ & $17^{\circ} 56^{\prime} 51^{\prime \prime} \mathrm{E}$ \\
\hline var221 & nod & $\mathrm{HU}$ & W Rede & 2 & Eth & 1 & - & - & $47^{\circ} 22^{\prime} 52^{\prime \prime} \mathrm{N}$ & $17^{\circ} 56^{\prime} 51^{\prime \prime} \mathrm{E}$ \\
\hline var222-23 & nod & $\mathrm{HU}$ & W Oroszlany & 2 & Eth & 2 & 2 & 2 & $47^{\circ} 29^{\prime} 27^{\prime \prime} \mathrm{N}$ & $18^{\circ} 21^{\prime} 31^{\prime \prime} \mathrm{E}$ \\
\hline 329 & nod & $\mathrm{DE}$ & Murnau & 3 & Eth & 1 & - & 1 & $47^{\circ} 39^{\prime} \mathrm{N}$ & $11^{\circ} 11^{\prime} \mathrm{E}$ \\
\hline JQ646615 & nod & FR & Vosges1 & 3 & GenB & 1 & - & - & $48^{\circ} 04^{\prime} \mathrm{N}$ & $07^{\circ} 10^{\prime} \mathrm{E}$ \\
\hline KU917778 & nod & DE & Vilshofen2 & 3 & GenB & 1 & - & - & $48^{\circ} 37^{\prime} 21^{\prime \prime} \mathrm{N}$ & $13^{\circ} 11^{\prime} 40^{\prime \prime} \mathrm{E}$ \\
\hline KM439236 & depres. & AT & Heiligenblut3 & - & GenB & 1 & - & - & & \\
\hline JQ646593 & irregul. & $\mathrm{HR}$ & Kapela Vrh1 & - & GenB & 1 & - & - & & \\
\hline JQ689919 & irregul. & RO & Resita4 & - & GenB & - & 1 & - & & \\
\hline
\end{tabular}

1 = Deuve et al. (2012); 2 = KuliK \& Ahrens, GenB; 3 = Hendrich et al. (2015); 4 = Andujar et al. (2012) 